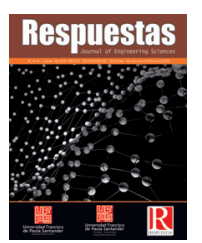

Original Article

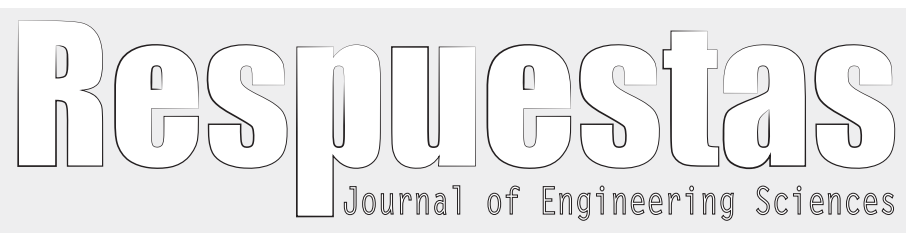

https://doi.org/10.22463/0122820X.1810

\title{
Effect of the recycled rubber grain in the rutting of an asphalt mixture type MD-12
}

\author{
Efecto del grano de caucho reciclado en el ahuellamiento de una mezcla asfáltica tipo MD-12 \\ Carlos Hernando Higuera-Sandoval ${ }^{1 *}$, Brandon Nicolás Olarte-Riaño ${ }^{2}$, Rubén David Soler-Sánchez ${ }^{3}$ \\ I*Magister en Ingeniería, carlos.higuera@uptc.edu.co, ORCID: 0000-0003-1333-2517, Universidad Pedagógica y Tecnológica de Colombia, Tunja, Colombia. \\ ${ }^{2}$ Ingeniero en Transporte y Vias, brandon.olarte@uptc.edu.co, ORCID: 0000-0003-4691-0299, Universidad Pedagógica y Tecnológica de Colombia, \\ Tunja, Colombia. \\ ${ }^{3}$ Ingeniero en Transporte y Vias, ruben.soler@uptc.edu.co, ORCID 0000-0002-1872-1506, Universidad Pedagógica y Tecnológica de Colombia, Tunja, Colombia.
}

How to cite: C. Higuera-Sandoval, B. Olarte-Riaño y R. Soler-Sánchez, "Effect of the recycled rubber grain in the rutting of an asphalt mixture type MD-12”. Respuestas, vol. 24, no. 1, pp. 84-94, 2019.

Received on June 10, 2018; Approved on October 31, 2018

\section{ABSTRACT}

Keywords:

Rutting

Plastic

deformation

Recycled rubber

grain (GCR)

Marshall

Asphalt mixture

Type MD-12

Currently in Colombia, a lot of used tires are generated which have not been provided with proper handling, for this reason, environmental problems are significant, therefore, there is a need to look for alternatives that encourage the reuse of waste from various recyclable materials and thus incorporate them into the production cycle, obtaining as a major benefit a reduction in the environmental impact caused by this type of waste. According to the above, the investigation analyzed the effect of the recycled rubber grain added by dry process, in the rutting of an asphaltic mixture type MD-12, through the plastic deformation resistance test standardized by the Instituto Nacional de Vías INVIAS in 2013 . The analysis was carried out using the Marshall methodology with the design of an asphalt mixture conventional MD-12 and three MD-12 asphalt mixtures with variations in the addition of GCR, the preliminary designs and verification of each of the asphalt mixes as established in the general construction specifications of the Instituto de Desarrollo Urbano IDU, obtaining the respective working formula of each asphalt mixture. Obtaining favorable behaviors in asphalt mixtures with addition of $0.5 \%$ of GCR in which there are decreases of up to $5.3 \%$ in the rutting, with respect to the asphaltic mixture of reference, also it highlights the improvements that the asphalt mixture presented in terms of resistance to plastic deformation or rutting, before the addition of rubber grain recycled by dry process, for this reason it is recommended to use it in asphalt mixtures type MD-12 as part of the fine aggregate and thus obtain a greater efficiency from the mechanical point of view, as well as the improvements in the useful life of the pavement and the mitigation of the environmental impacts generated by the mishandling of tires out of use in the country.

\section{RESUMEN}

\section{Palabras clave:}

Ahuellamiento

Deformación

plástica

Grano de caucho

reciclado (GCR)

Marshall

Mezcla asfáltica

Tipo MD-12
Colombia actualmente genera una gran cantidad de llantas usadas a las cuales no se les proporciona un manejo adecuado, debido a esto, los problemas ambientales son significativos, por lo tanto, surge la necesidad de buscar alternativas que fomenten la reutilización de residuos de diversos materiales reciclables y de esta manera incorporarlos al ciclo productivo, obteniendo como mayor beneficio una disminución del impacto ambiental que ocasionan este tipo de residuos. De acuerdo con lo anterior, la investigación analizó el efecto del Grano de Caucho Reciclado (GCR) adicionado por vía seca, en el ahuellamiento de una mezcla asfáltica tipo MD-12, mediante el ensayo de resistencia a la deformación plástica normalizado por el Instituto Nacional de Vías INVIAS en 2013. El análisis se realizó empleando la metodología Marshall con el diseño de una mezcla asfáltica tipo MD-12 convencional y tres mezclas asfálticas tipo MD-12 con variaciones en la adición de GCR, los diseños preliminares y verificación de cada mezcla asfáltica se realizaron según lo establecido en las especificaciones generales de construcción del Instituto de Desarrollo Urbano IDU, obteniendo la respectiva fórmula de trabajo de cada mezcla asfáltica. Obteniendo comportamientos favorables en mezclas asfálticas con adición de $0.5 \% \mathrm{GCR}$, en las cuales se presentan disminuciones de hasta $5.3 \%$ en el ahuellamiento, respecto a la mezcla asfáltica convencional, además se destacan las mejoras

*Corresponding author.

E-mail address: carlos.higuera@uptc.edu.co (Carlos Hernando Higuera Sandoval)

(c) $(1) \Theta$ Peer review is the responsibility of the Universidad Francisco de Paula Santander

cc) This is an article under the license CC BY-ND (http://creativecommons.org/licenses/by-nc-nd/4.0/). 
que presentó la mezcla asfáltica en cuanto a resistencia a deformación plástica, ante la adición del grano de caucho reciclado por vía seca, por esta razón se recomienda emplearlo en mezclas asfálticas tipo MD-12 como parte del agregado fino y así obtener una mayor eficiencia desde el punto de vista mecánico, así como las mejoras en la vida útil del pavimento y la mitigación de los impactos ambientales que genera el mal manejo de llantas fuera de uso en el país.

\section{Introduction}

Communication between different areas of a territory plays a fundamental role in its economic and social development, so it is considered that road infrastructure should be considered as one of the main aspects to be taken into account in the planning and development plans of a region, thus guaranteeing conditions of safety, comfort and economy to the users, being the investment in road infrastructure a strategic component for the development of the country [1].

According to statistics from the Ministry of Transportation of 2017, Colombia has $205937 \mathrm{~km}$ of road network, of which only $15432.4 \mathrm{~km}$ are paved (7.5\%). Approximately $47.3 \%$ of the national road network has deteriorations and several representative damages which considerably reduces its useful life, only $19.5 \%$ of the network is in good condition, this is mainly due to the pavement construction process, so which is necessary the implementation of materials that contribute to the quality, capacity and durability of the structures [2].

According to this, a series of investigations have been developed in which it is sought to evaluate the usefulness of some recyclable materials, which are transformed into new products or materials, thus incorporating into the productive cycle, highlighting materials such as paper, plastic, glass, rubber and metals [3]. Asphalt mixtures have been evaluated in recent years with the addition of materials such as synthetic fibers [4], PVC polyvinyl chloride [5], polyethylene PEBD [6], blast furnace slags [7], [8], among others, which allow improvements in the mechanical properties of asphalt mixtures [9] and in the same way they contribute to the mitigation of different environmental problems associated with the mishandling of the waste of said materials.

By deepening the modification and improvement of asphalt mixtures with recycled rubber grain (GCR) it has been found that this considerably improves the mechanical properties of asphalt mixtures, increasing their useful life and reducing maintenance costs over the operating time, in addition to mitigating environmental problems by reusing discarded tires, which generates a decrease in the emission of volatile organic compounds to the environment, in manufacturing processes and construction of infrastructure projects [10].

This use given to the rubber grain is an alternative to obtain an important benefit such as environmental sustainability in the production of asphalt mixtures [11], In addition, it is considered that the use of the GCR in the design of asphalt mixtures can significantly improve the properties of the mixtures, which can be reflected in the decrease in the thicknesses of asphalt layers, providing a longer useful life, as well as an increase in fatigue resistance and decrease in pavement rutting, which translates into decreased maintenance costs [12].

According to figures from the Ministry of Environment, Housing and Territorial Development in the environmental diagnosis on the generation of used tires, approximately 190,500 tons of waste are produced annually from the recycling of tires, of which only $10 \%$ are reused in another type of production, the rest goes to landfills $(50 \%)$ or are incinerated $(40 \%)$, which generates countless effects on the environment [13], which shows that there is a need to look for options that allow proper management of this type of waste in order to encourage the reuse of rubber waste and thus reduce its environmental impact and generate new alternatives for job creation in the country [14].

For some time it has been considered reliable to add recycled rubber grain in asphalt mixtures for its modification (wet way) and / or improvement (dry way), because in addition to mitigating environmental 
problems by reusing the tires discarded by the decrease in Emission of volatile compounds, the mechanical properties of asphalt mixtures are considerably improved, such as: increased fatigue resistance, decreased rutting and increased useful life, reducing maintenance costs over the operating time [15] - [18].

The plastic deformation is one of the most important variables in the control of the design of a pavement structure, so it is important to determine rutting values which will be used in the design of layer thicknesses, some factors that affect the deterioration and low performance of the track in its operational stage, it is for this reason that rutting is considered a significant variable to analyse, being important to observe and analyse the behaviour of the same before the addition of recycled rubber grain.

Different strategies have been developed by Colombian institutions which once analysed the possible use of the GCR in asphalt mixtures have adopted measures that encourage the use of the GCR as a modifier of asphalt mixtures, among which is Decree 265 of 2016, which indicates that all transport infrastructure work that is carried out in the Capital District and further construction processes with asphalts, must include the use of materials from the use of used tires in a percentage not less than $25 \%$ of the total volume of asphalt mixtures used on vehicular roads [19].

Similarly, INVIAS has established for $4 \mathrm{G}$ concession highway projects, to incorporate incentives and requirements for contractors, which consist of assigning up to 100 points to bidders who commit to include in their proposal the implementation of asphalt mixtures with grain of recycled rubber (GCR) in a length not less than $10 \%$ of the total project [20].

The research is part of the projects being carried out by the Road Infrastructure Research and Development Group-GRINFRAVIAL- of the School of Transportation and Roads categorized by Colciencias in category $\mathrm{C}$, which has been called "Effect of rubber grain in the Routing of an asphalt mix type MD-12", and is mainly limited to the analysis of the mechanical efficiency of an asphalt mix through the study of the behavior of rutting, performing an asphalt mix with dry addition of different percentages of rubber grain Recycled and thus be able to determine the optimal percentage of GCR for hot dense asphalt mixtures and through this reach a technical relationship that allows generating a comparison criterion for an MD-12 type asphalt mixture and a T2-T3 transit level according to specifications IDU.

\section{Materials and methods}

To analyze the effect of recycled rubber grain in the routing of the MD-12 type asphalt mixture, a work methodology is following based on the General Technical Specifications of Construction of the Institute of Urban Development of Bogotá IDU 2011, making the characterization of the selected materials for the preparation of the asphalt mixture.

\section{Characterization of the aggregated stones}

One of the fundamental parameters in the design of an asphalt mixture is the characterization of stone aggregates, these materials must have an adequate handling and a demanding control in compliance with the specification since it depends largely on obtaining an optimum Asphalt mix design, for this investigation stone aggregates were used from the Crushed quarry Paz del Rio quarry, located in the department of Boyacá.

\section{Granulometry of the aggregates}

Three types of material (gravel, crushing sand and rock sand) were supplied by the quarry, to which the respective granulometry was carried out, to subsequently carry out a dosage that manages to adjust to the granulometric strip established by the IDU in Article 510-11, obtaining the granulometry

Table I. MD-12 dosage granulometry

\begin{tabular}{|c|c|c|}
\hline Sieve & Opening $\mathbf{~ m m}$ & Check, \% \\
\hline $3 / 4 "$ & 19.00 & 100.0 \\
\hline $1 / 2 "$ & 12.50 & 88.6 \\
\hline $3 / 8^{\prime \prime}$ & 9.50 & 81.3 \\
\hline $\mathrm{N}^{\circ} 4$ & 4.750 & 56.4 \\
\hline $\mathrm{N}^{\circ} 10$ & 2.000 & 39.3 \\
\hline $\mathrm{N}^{\circ} 40$ & 0.425 & 19.2 \\
\hline $\mathrm{N}^{\circ} 80$ & 0.180 & 11.8 \\
\hline $\mathrm{N}^{\circ} 200$ & 0.075 & 5.7 \\
\hline
\end{tabular}


presented in Table I, thus determining the following proportions: Gravel $35 \%$, crushing sand $50 \%$ and reef sand $15 \%$.

From this, the granulometric curve corresponding to the dosage presented above is performed. Next, Figure 1 shows the adjustment to the granulometric range of an asphalt mixture type MD-12 including the corresponding tolerances applicable in production on the working formula.

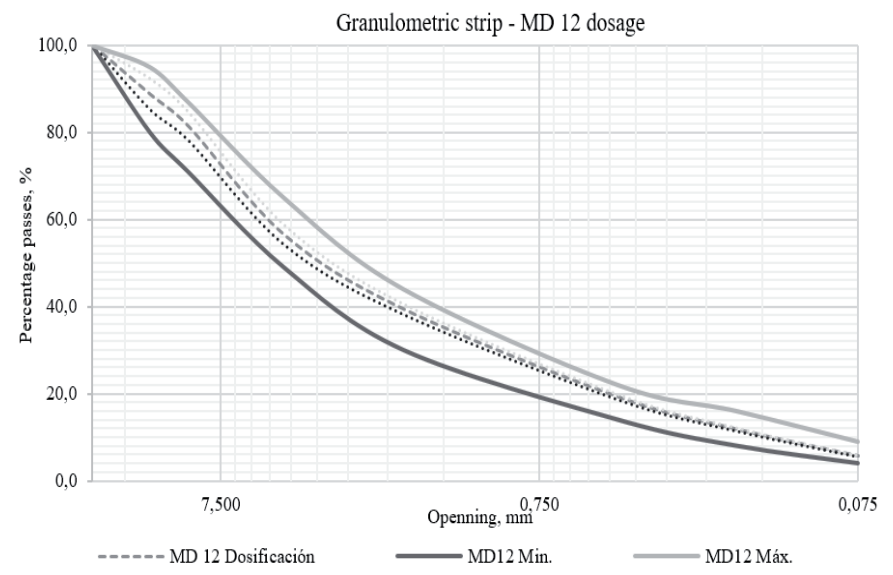

Figure 1. Granulometric strip - MD-12 dosage

\section{Characterization tests}

Once the granulometry of the stone aggregate defined, it is necessary to proceed to characterize it by means of laboratory tests with which it is possible to verify compliance with the requirements stipulated in the specifications and in this way to be able to continue with the design of the MD-12 type asphalt mixture. In Table II, the results presented after determining the bulk specific gravity for each of the stone aggregate fractions.

Table II. Specific Gravity of the Aggregates

\begin{tabular}{|c|c|c|}
\hline Material & Specific Gravity Ratio & Specific Gravity Ratio \\
\hline Thick Aggregate & $43.6 \%$ & 2.597 \\
\hline Fine aggregate & $50.7 \%$ & 2.654 \\
\hline Filler (filling) & $5.7 \%$ & 2.548 \\
\hline
\end{tabular}

Finally, the characterization was carried out in order to evaluate the requirements and the behavior of the aggregates, according to the IDU specifications. Table III shows the results obtained in the laboratory corresponding to the characterization of the aggregates.
Table III. Characterization of aggregates for MD-12

\begin{tabular}{|c|c|c|c|c|}
\hline \multicolumn{5}{|c|}{ CHARACTERIZATION OF AGGREGATES FOR MD-12 ASPHALT MIX } \\
\hline Characteristic & Standard INV.E- & $\begin{array}{c}\text { Requirement } \\
\text { T2-T3 }\end{array}$ & Test & Observation \\
\hline \multicolumn{5}{|c|}{ HARDNESS } \\
\hline Wear Los Angeles 500 Rev. (\% max.) & $218-13$ & 30 & 16.7 & FULFILL \\
\hline Micro Deval (\% max.) & $238-13$ & 25 & 13.9 & FULFILL \\
\hline $10 \%$ fine, dry value ( $\min \min )$. & $224-13$ & 75 & 125.4 & FULFILL \\
\hline \multicolumn{5}{|c|}{ DURABILITY } \\
\hline Sulf fastness. Thick magnesium (\% max.) & \multirow{2}{*}{$220-13$} & \multirow{2}{*}{18} & 1.4 & FULFILL \\
\hline Sulf fastness. Fine magnesium (\% max.) & & & 1.6 & FULFILL \\
\hline \multicolumn{5}{|c|}{ GEOMETRY } \\
\hline 1 Face fractured particles $(\% \mathrm{~min})$. & \multirow{2}{*}{$227-13$} & 75 & 100 & FULFILL \\
\hline 2 -sided fractured particles $(\% \mathrm{~min})$. & & 50 & 100 & FULFILL \\
\hline Flattening index (\% max.) & \multirow{2}{*}{$230-13$} & 25 & 10.6 & FULFILL \\
\hline Elongation rate $(\%$ max. $)$ & & 25 & 6.3 & FULFILL \\
\hline Angularity of the fine fraction $(\% \mathrm{~min})$. & $239-13$ & 45 & 48.2 & FULFILL \\
\hline \multicolumn{5}{|c|}{ CLEANING } \\
\hline Agr. Impurities Thick (\% max.) & $237-13$ & 0.5 & 0.32 & FULFILL \\
\hline Plasticity index (\% max.) & $126-13$ & NP & $N P$ & FULFILL \\
\hline Sand equivalent (\% min.) & $133-13$ & 40 & 66 & FULFILL \\
\hline Methylene blue value (mg / g max.) & $235-13$ & 8 & 5 & FULFILL \\
\hline
\end{tabular}

\section{Characterization of the asphalt cement}

Asphalt cement for the preparation of the asphalt mixture is selected based on the climatic characteristics of the area, the type of layer and the operating conditions of the road, as indicated by the IDU in section 510-11, establishing a Type of asphalt cement AC 80-100, provided by the company MPI Ltda. (Manufacturing and Industrial Processes) located in the municipality of Barrancabermeja, for its characterization, it must be evaluated in different laboratory tests, according to the specifications IDU in section 200-11, in Table IV, the compliance with the requirements for the AC 80-100 asphalt cement used in the investigation is evidenced.

Table IV. Asphalt cement characterization

\begin{tabular}{|c|c|c|c|c|c|}
\hline \multicolumn{6}{|c|}{ AC 80-100 ASPHALT CEMENT CHARACTERIZATION } \\
\hline Characteristic & Standard INV.E- & Mín. & Máx. & Test & Observation \\
\hline \multicolumn{6}{|c|}{ ORIGINAL ASPHALT } \\
\hline Penetration $(0.1 \mathrm{~mm})$ & $706-13$ & 80 & 100 & 97 & FULFILL \\
\hline Penetration rate & $724-13$ & -1.0 & +1.0 & -0.76 & FULFILL \\
\hline Viscosity at $60^{\circ} \mathrm{C}(\mathrm{Pa} * \mathrm{~s})$ & $717-13$ & 100 & 200 & 131 & FULFILL \\
\hline Softening point $\left({ }^{\circ} \mathrm{C}\right)$ & $712-13$ & 42 & 52 & 45.4 & FULFILL \\
\hline Ductility $(\mathrm{cm})$ & $702-13$ & 100 & - & $>120$ & FULFILL \\
\hline Flash point Cleveland Open $\mathrm{Cup}\left({ }^{\circ} \mathrm{C}\right)$ & $709-13$ & 232 & - & 294 & FULFILL \\
\hline \multicolumn{6}{|c|}{ RESIDUAL ASPHALT - Rotary thin sheet aging INV.E - 720-13 } \\
\hline Loss of mass due to heating (\%) & $720-13$ & - & 1 & 0.3 & FULFILL \\
\hline $\begin{array}{l}\text { Penetration of the residue as a percentage } \\
\text { of the original penetration }(0.1 \mathrm{~mm})\end{array}$ & $721-13$ & 50 & - & 56.1 & FULFILL \\
\hline Increase in softening point $\left({ }^{\circ} \mathrm{C}\right)$ & $712-13$ & - & 9 & 7.2 & FULFILL \\
\hline Aging-viscosity index at $60^{\circ} \mathrm{C}$ & $717-13$ & - & 5 & 3.2 & FULFILL \\
\hline
\end{tabular}

For the manufacture of the asphalt mixture it is important to know the geological curve of the asphalt cement which is presented below in Figure 2 , this is achieved from the viscosity determination test using the Brookfield rotational viscometer obtaining for the asphalt cement AC 80-100 used in the investigation, a mixing temperature of $145^{\circ} \mathrm{C}$ and compaction temperature of $134^{\circ} \mathrm{C}$. 


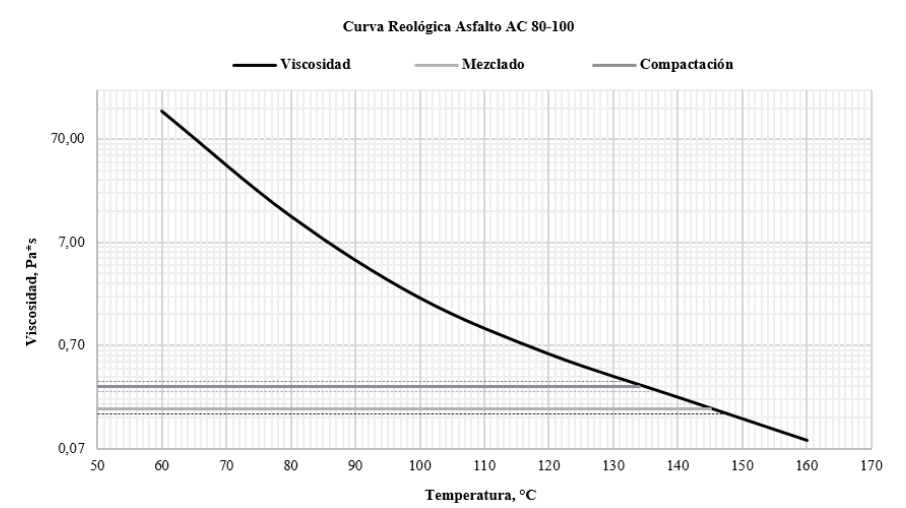

Figure 2. Asphalt cement rheological curve AC 80-100

\section{Recycled rubber grain (GCR)}

The recycled rubber grain (GCR) is a material obtained from the processing of tires, which have already exhausted their useful life, and become obsolete, these tires mainly belong to vehicles. It is mainly obtained from the crushing of the tires, in this process, a separation of its three main elements is carried out rubber, steel, and textile fibers [21].

\section{Characterization of recycled rubber grain}

The recycled rubber grain was supplied by the company RECICLAIR SAS that produces rubber particles for the different fields of application of the rubber grain in recycling with different sizes. From the granulometry carried out to the recycled rubber grain, a greater quantity of medium to fine gradation material can be established, which is considered to be taken in the research work, for the addition in the asphalt mixture the sieves No. 10, No. 40 and No. 80 These sizes are shown in Figure 3. For the design of the asphalt mixture, it is necessary to determine the specific gravity of the rubber grain, obtaining a Gs value of 0.5 .

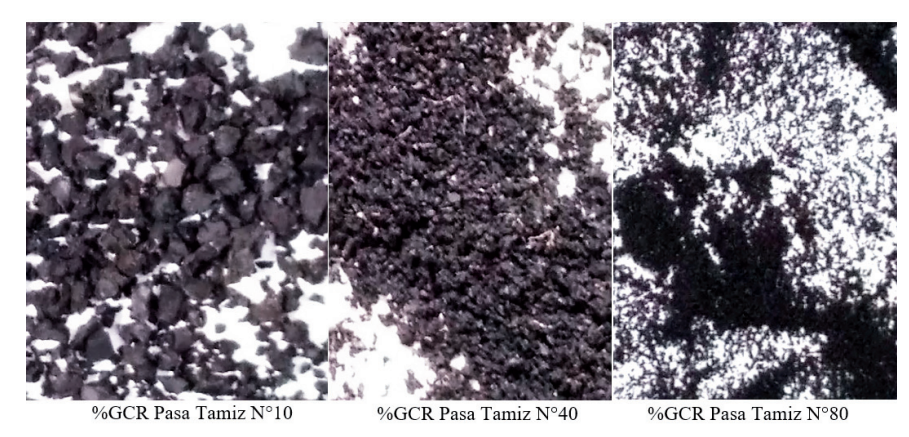

Figure 3. Sizes of GCR added by dry route

\section{Chemical composition of the GCR}

The chemical composition of the rubber grain is important considering that in addition to the components related to natural or synthetic rubber that has a tire, there are a number of chemical elements or compounds that are part of and influence the main characteristics of a tire, in Table V, these chemical elements are presented [22].

Table V. Chemical composition of the GCR

\begin{tabular}{|c|c|c|}
\hline Element & Symbol Composition, $\%$ & Symbol Composition, $\%$ \\
\hline Carbon & $\mathrm{C}$ & 70 \\
\hline Hydrogen & $\mathrm{H}$ & 7 \\
\hline Sulfur & $\mathrm{S}$ & 1 \\
\hline Chlorine & $\mathrm{Cl}$ & 0.5 \\
\hline Iron & $\mathrm{Fe}$ & 15 \\
\hline Zinc oxide & $\mathrm{ZnO}$ & 2 \\
\hline Silicon dioxide & $\mathrm{SiO}_{2}$ & 4.5 \\
\hline
\end{tabular}

Source: [22]. Use of tire rubber dust on asphalt pavements.

\section{Addition of the GCR to the asphalt mixture}

For the manufacture of the MD-12 type asphalt mixture, the rubber grain was added by dry way, currently this process has a reduced application due to the lack of experiences in its use, in Colombia there is no specification that serves of guidance for the use of the GCR in the design of asphalt mixtures and its implementation. By dry process, the process observed in Figure 4 consists in mixing the GCR rubber grain together with the aggregates, that is, this would act as a replacement for a fraction or percentage of the aggregates used in the manufacturing of the asphalt mixture [8].

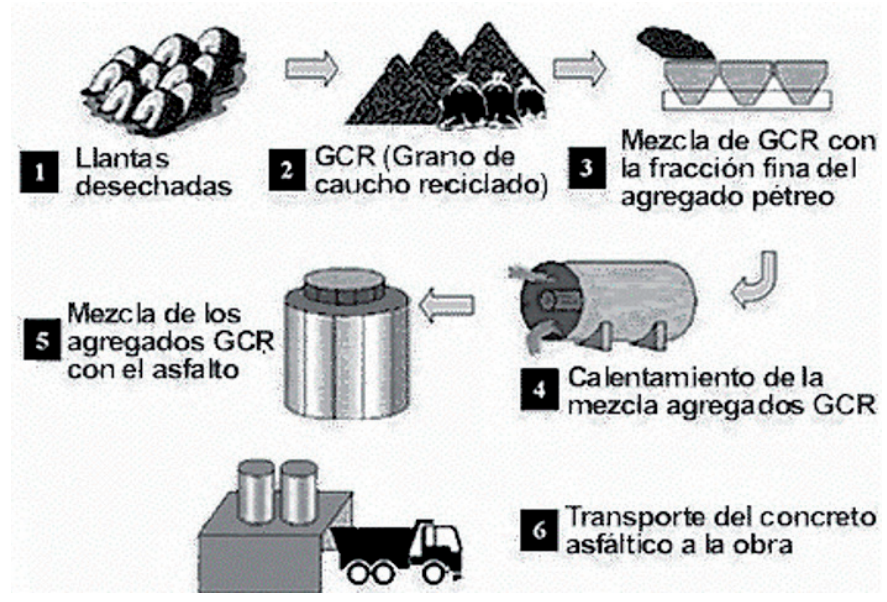

Figure 4. GCR Addition Process - Vía Seca Fuente. [12] 
When adding dry recycled rubber grain as an asphalt mix improver, it should be ensured that this material has properties that allow an effective interaction with stone aggregates, according to this the so-called digestion process has been developed, which starts from the surface of the particle inwards, and it will be faster the thinner the rubber grain, the lower its proportion within the asphalt mixture and the higher the temperature of the mixture and the time it is kept warm during the process of manufacturing and compaction [11], [23].

In the case that the digestion process is not carried out correctly, an adequate reaction will not occur in which the GCR interacts with the asphalt cement and the stone aggregates, whereby an asphalt mixture of inefficient behavior will be obtained. In the present investigation, the digestion time to which the GCR was subjected to obtain the best mixing conditions is two (2) hours at a temperature of $170^{\circ} \mathrm{C}$ [11].

\section{Results and Discussion}

The main objective of the investigation is to determine the effect of the addition of recycled rubber grain in an MD-12 type asphalt mixture. Once each of the asphaltic analysis mixtures was verified, the plastic deformation resistance test was carried out in accordance with the INV test standard. E-756-13.

\section{MD-12 asphalt mix plastic deformation}

Rutting is a property that gives notion of the permanent deformations that occur on the pavement, mainly in the asphalt binder, to know the behavior of this property; the plastic deformation curves obtained from the laboratory track test are performed.

The test for the determination of the resistance to plastic deformation was carried out using the laboratory track, conditioned at a temperature of $60^{\circ} \mathrm{C}$ applying a load with contact pressure of $7 \mathrm{Kg} / \mathrm{cm}^{2}$ for a period of 120 minutes. Next, the results obtained for each of the asphalt mixtures manufactured to perform the respective comparison and analysis will be presented.

\section{Conventional MD-12 plastic deformation}

Initially, the conventional MD-12 asphalt mixture was tested, after the test time has elapsed, the plastic deformation curve for the conventional MD-12 type asphalt mixture observed in Figure 5 is performed. In which the equation that It best conforms to the exponential behavior of the rutting presented in the conventional MD-12 asphalt mixture, obtaining a total deformation of $5.7 \mathrm{~mm}$ at a speed of $16.7 \mu \mathrm{m} /$ $\mathrm{mm}$.

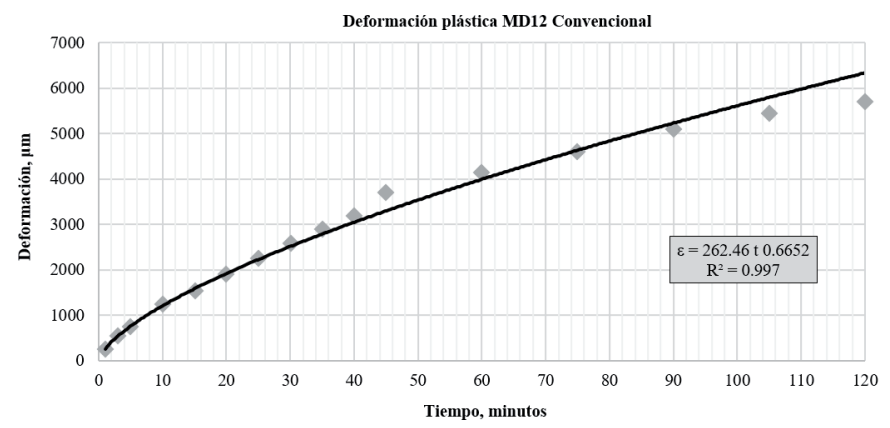

Figure 5. Conventional MD-12 plastic deformation curve

\section{MD-12 plastic deformation with 0.5\% GCR addition}

The same test procedure was performed, for the asphalt mixture with the addition of $0.5 \%$ recycled rubber grain, obtaining the behavior observed in Figure 6 corresponding to the plastic deformation curve for this asphalt mixture.

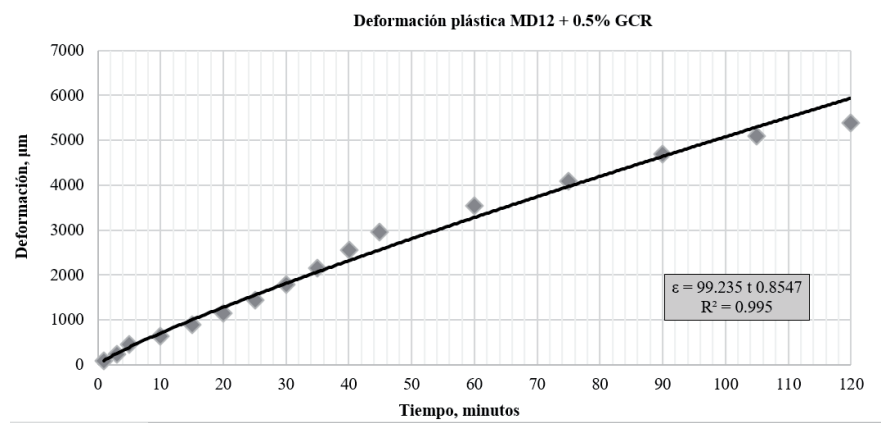

Figure 6. MD-12 plastic deformation curve with $0.5 \%$ GCR addition

In the deformation curve an exponential behavior is observed and the equation that best fits the rutting presented in the MD-12 asphalt mixture with $0.5 \%$ GCR addition, obtaining a total deformation of 5.4 $\mathrm{mm}$ at a speed of $20.0 \mu \mathrm{m} / \mathrm{mm}$ 


\section{MD-12 plastic deformation with $1.5 \%$ GCR addition}

In the same way, the MD-12 type asphalt mixture was added with an addition of $1.5 \%$ of rubber grain, the test is carried out under the same conditions of time, contact pressure and temperature, obtaining the plastic deformation curve presented in the Figure 7. Evidence of a total deformation of $10.8 \mathrm{~mm}$ developing a deformation speed $33.3 \mu \mathrm{m} / \mathrm{mm}$. The deformation curve shows the equation that best fits the exponential behavior of the rutting presented in the asphalt mixture.

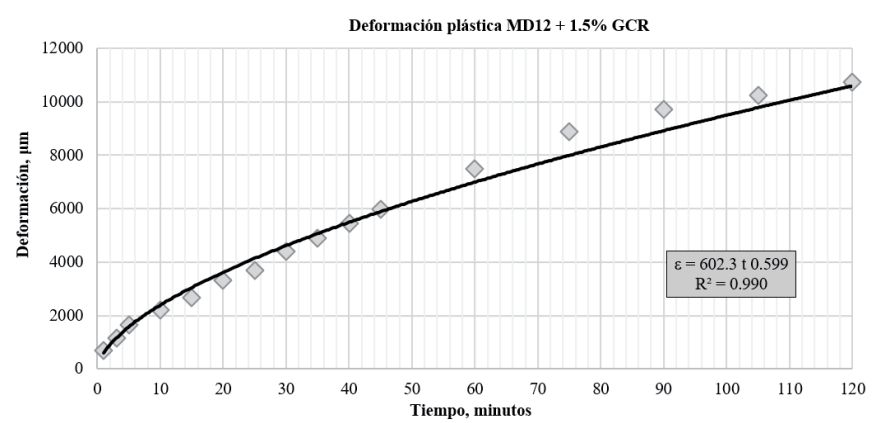

Figure 7. MD-12 plastic deformation curve with 1.5\% GCR addition

MD-12 plastic deformation with 2.5\% GCR addition

Finally, the highest addition MD-12 asphalt mixture was evaluated with $2.5 \%$ GCR. With the average deformation values, the plastic deformation curve was performed for this asphalt mixture, which has an exponential behavior and is observed in Figure 8. Obtaining the equation as a function of the load application time that best fits the behavior of the rutting presented in the MD-12 asphalt mix with an addition of $2.5 \%$ recycled rubber grain, presenting a total deformation of $13.7 \mathrm{~mm}$ reaching a 40.0 deformation rate $\mu \mathrm{m} / \mathrm{mm}$.

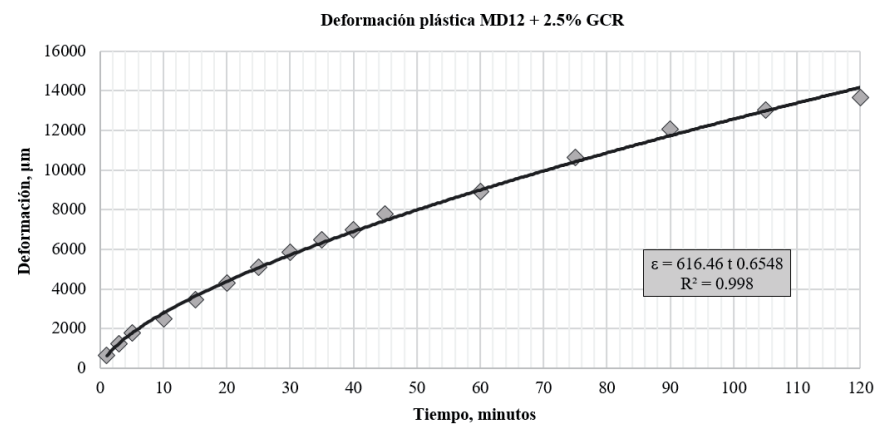

Figure 8. MD-12 plastic deformation curve with $2.5 \%$ GCR addition

\section{MD-12 asphalt mixing rutting comparison}

It is necessary to make a comparison of how the addition of dry recycled rubber grain influences the rutting of an MD-12 type asphalt mixture, which was designed for a transit level T2-T3. The behavior of the deformations always develops an exponentially growing trend, initially the comparison of the deformations obtained in each of the asphalt mixtures will be carried out taking as reference the conventional MD-12 type asphalt mixture, for this the plastic deformation curves will be used, as shown in Figure 9.

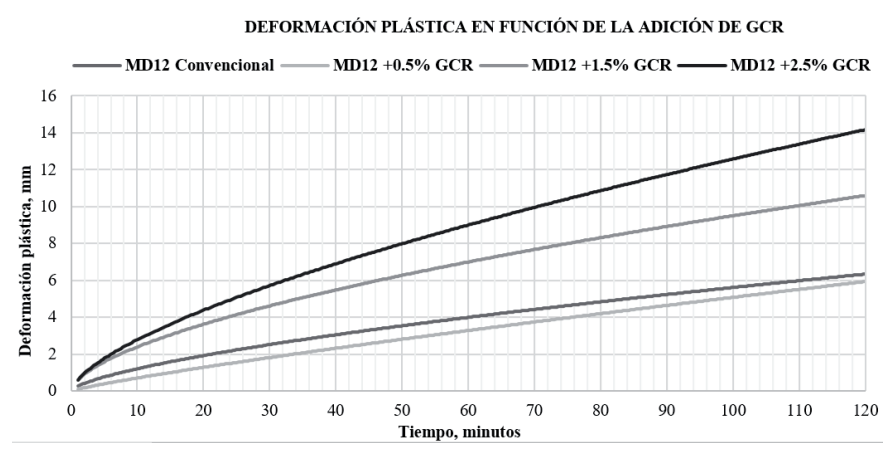

Figure 9. Plastic deformation curves depending on the addition of GCR

The MD-12 type asphalt mix with the addition of $0.5 \%$ recycled rubber grain shows a decrease in the recorded deformation values, compared to the conventional MD-12 asphalt mix, this result gives an idea of an improvement in the mechanical properties of the asphalt mixing, because rutting is one of the most common failures in a pavement structure, so it can be considered feasible to add recycled rubber grain for this type of mixture and at least in this proportion of $0.5 \%$.

The opposite occurs with the remaining asphalt mixtures, since both for the MD-12 asphalt mixture with the addition of $1.5 \%$, as well as the addition of $2.5 \%$ of GCR, it is observed that the deformations increase considerably compared to the conventional mixture, which indicates that in the case of larger rubber grain additions, the asphalt mixture would no longer have optimal and adequate operating properties in terms of its operation.

To make a more detailed evaluation of the influence of the addition by dry use of recycled rubber grain on the mechanical properties of the asphalt mix type 
MD-12, a comparison was made between the final routing values that occurred after 120 minutes test, under normalized contact pressure and temperature conditions. These values are presented in Figure 10.

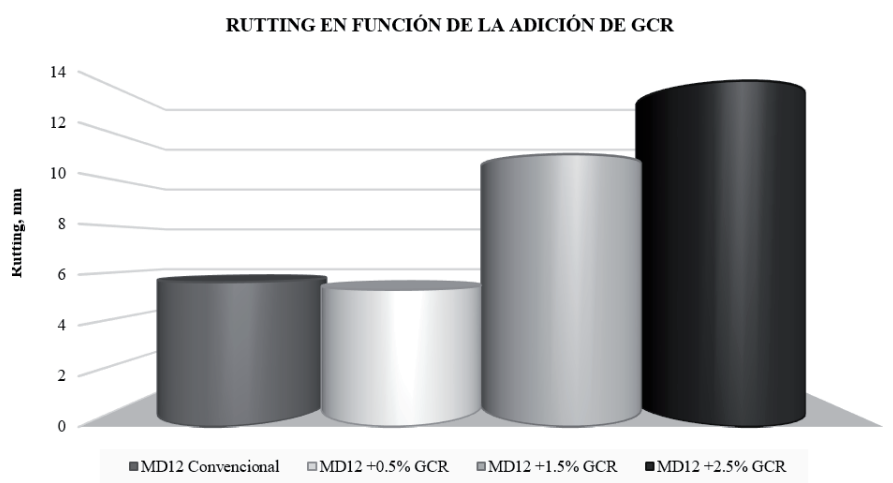

Figure 10. Rutting based on the addition of GCR

The conventional MD-12 asphalt mixture has an asphalt content of $5.2 \%$ and reached a maximum deformation of $5.7 \mathrm{~mm}$, these values will serve as a reference for comparisons regarding the property of resistance to plastic deformation or rutting.

As noted, the MD-12 asphalt mixture with a $0.5 \%$ GCR addition has better resistance properties to plastic deformation because the rutting values obtained are lower than the reference ones. In this case, the asphalt mix has an asphalt content of 5.5\% and presented a maximum deformation value of 5.4 $\mathrm{mm}$, which translates into a 5\% decrease in rutting compared to conventional MD-12.

When adding GCR to the asphalt mixture by $1.5 \%$, considerable variations in its properties begin to be observed, as observed in the case of rutting, this asphalt mixture with asphalt content of $6.2 \%$ presented a maximum deformation value of 10.75 $\mathrm{mm}$, which allows establishing that the behavior of the asphalt mixture before the loads imposed by traffic cannot be very favorable, since there is an $89 \%$ increase in rutting.

Finally, we have the MD-12 asphalt mixture with 2.5\% GCR addition, which has the most unfavorable behavior in terms of deformation resistance, for this mixture an optimum asphalt content of $6.4 \%$ was determined and I present a maximum deformation of $13.65 \mathrm{~mm}$ after 120 minutes of testing, which represents a $139 \%$ increase in the rutting value compared to the conventional MD-12 asphalt mix.

\section{Deformation Speeds Comparison}

Another important variable to analyze the routing of an asphalt mixture is the deformation rate, Colombian standards suggest determining the deformation rates for three intervals such as: $30-45$, 75-90 and 105-120 minutes, the latter being that of greater use considering that it is the time interval in which the behavior of the asphalt mixture being tested is evidenced more clearly and precisely, taking into account the last comparison that was made was between deformation rates obtained which are expressed in $\mu \mathrm{m} / \mathrm{min}$ and are presented in Table VI.

Table VI. Warp speed depending on the addition of GCR

\begin{tabular}{|c|c|c|c|c|}
\hline $\begin{array}{c}\text { MD-12 } \\
\text { Asphalt } \\
\text { Mix }\end{array}$ & conventional & $\mathbf{+ 0 . 5 \%}$ GCR & $\mathbf{+ 1 . 5 \%}$ GCR & $\mathbf{+ 2 . 5 \%}$ GCR \\
\hline $\begin{array}{c}\text { Rutting } \\
(120 \\
\text { min) }\end{array}$ & $5.7 \mathrm{~mm}$ & $5.4 \mathrm{~mm}$ & $10.8 \mathrm{~mm}$ & $13.7 \mathrm{~mm}$ \\
\hline $\begin{array}{c}\text { Speed } \\
(105- \\
120 \\
\text { min })\end{array}$ & $16.7 \mu \mathrm{m} / \mathrm{min}$ & $20.0 \mu \mathrm{m} / \mathrm{min}$ & $33.3 \mu \mathrm{m} / \mathrm{min}$ & $40.0 \mu \mathrm{m} / \mathrm{min}$ \\
\hline
\end{tabular}

From these values of deformation velocities obtained in each of the asphalt mixtures designed, Figure 11 shows how the velocity behavior is directly proportional to the addition of recycled rubber grain because as it increases the proportion of GCR in the asphalt mixture, the rate of deformation will increase.

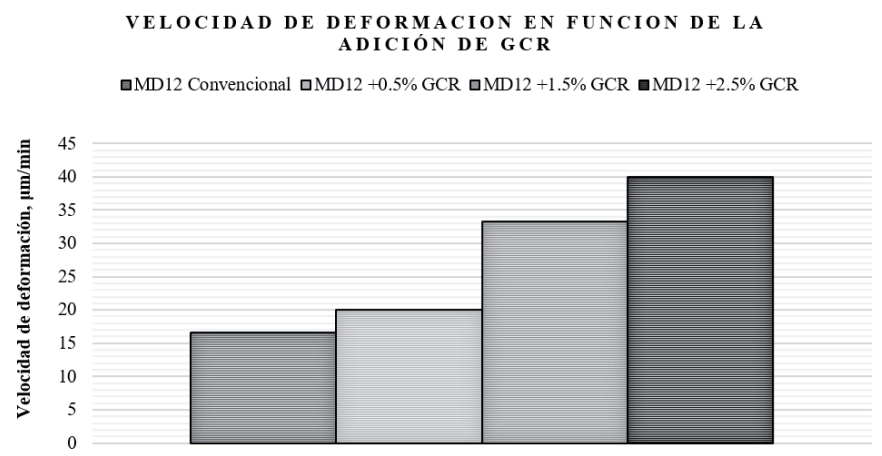

Figure 11. Plastic deformation curves according to the addition of GCR

The conventional MD-12 asphalt mix has a deformation rate of $16.7 \mu \mathrm{m} / \mathrm{min}$ which will serve as a reference for the respective comparison. The asphalt mixture with $0.5 \%$ of GCR has shown a better performance in terms of plastic deformation 
values, but in this case comparing the deformation rates a value of $20 \mu \mathrm{m} / \mathrm{min}$ was presented which is greater than the conventional asphalt mixture in a $20 \%$.

For the two remaining asphalt mixtures, the tendency is maintained, that is, by adding GCR the asphalt, mixture does not exhibit the expected behavior and its properties vary considerably unfavorably since its speeds are much higher than that presented by the conventional asphalt mixture having increases up to $140 \%$.

\section{Conclusions}

In this investigation it was possible to determine the effect represented by the addition of recycled rubber grain in the mechanical properties of an asphalt mixture, mainly in rutting, for this purpose a hot dense asphalt mixture type MD-12 was worked for a transit level T2 -T3 designed according to the specifications of the IDU Urban Development Institute, using the recycled rubber grain added by dry way as an asphalt mix improver material, with variations of the $0.5 \%, 1.5 \%$ and $2.5 \%$.

The results of the rutting test performed on the MD-12 asphalt mixture with an addition of $0.5 \%$ recycled rubber grain showed a favorable trend that can be highlighted, in terms of the influence that the addition of GCR can have as a material improving the mechanical properties of an asphalt mixture, this is due to the fact that the value of plastic deformation at the end of the test period was $5.4 \mathrm{~mm}$, that is, it showed a $5.3 \%$ decrease in its rutting compared to the conventional MD-12 asphalt mixture, due to On the other hand the deformation rate that developed was $20 \mu \mathrm{m} / \mathrm{min}$ which is acceptable.

As for the two remaining asphalt mixtures with the addition of rubber grain, the results are not favorable, because both showed high values of rutting and deformation speed; The MD-12 asphalt mix with $1.5 \%$ GCR added a total deformation of $10.8 \mathrm{~mm}$, approximately $90 \%$ more than that obtained in the conventional MD-12 asphalt mix, in the same way the deformation rate has a high value of $33.3 \mu \mathrm{m} / \mathrm{min}$.

The MD-12 asphalt mixture with the addition of $2.5 \%$
GCR is the one that presents the most unfavorable results since its total deformation at the end of the test was $13.7 \mathrm{~mm}$ which represents an increase of $140 \%$ with respect to the deformation obtained in the mixture Conventional MD-12 type asphalt and the deformation rate that developed was $40 \mu \mathrm{m} / \mathrm{min}$, which is considered significantly high.

\begin{tabular}{|c|c|c|}
\hline Asphalt Mix & Behavior & Variation \\
\hline MD-12 Conventional & Reference & - \\
\hline MD-12+ 0.5\% GCR & Decreases & $-5.3 \%$ \\
\hline MD-12+1.5\% GCR & Increases & $+89.5 \%$ \\
\hline MD-12+2.5\% GCR & Increases & $+140.4 \%$ \\
\hline
\end{tabular}

In general, a marked trend in the rate of deformation was obtained, because as the proportion of GCR addition to the asphalt mixture increases, the rate of deformation increases significantly, on the other hand it was obtained that Asphalt mixtures with $1.5 \%$ and $2.5 \%$ recycled rubber grain additions have the highest rutting values, this behavior can also be associated with the high asphalt contents that are required for these asphalt mixtures to have properties that meet the requirements of the IDU construction specifications regarding its design.

Once the results of plastic deformation for each of the asphalt mixtures under study were evaluated, $0.5 \%$ of GCR is considered as the optimal percentage of addition to the MD-12 type asphalt mixture because with this, the best results were obtained, by adding it dryly in rolling layers for a T2-T3 traffic level, according to the general construction specifications of the Bogotá IDU Urban Development Institute.

\section{Acknowledgment}

To the Road Infrastructure Research and Development Group - GRINFRAVIAL - of the School of Transport and Roads, to the Pedagogical and Technological University of Colombia for facilitating and making available to us the facilities and equipment of the Soil and Pavement Laboratory - LSP, to take The present investigation is successful.

\section{References}

[1] J. Camacho, L. Neme and O. Reyes, "Comportamiento de mezclas asfálticas cerradas mediante la aplicación del ensayo 
Fénix", Ciencia e Ingeniería Neogranadina, vol. 23, no. 2, pp. 17-36, 2013. doi: 10.18359/ rcin. 221

[2] Ministerio de Transporte, Oficina Asesora de Planeación, "Transporte en cifras-Estadísticas 2017”, Bogotá D.C., Colombia. Cuadros T14, T16 y $T 17,2018$.

[3] F. Victoria, L. Marmolejo and P. Torres, "Alternativas para fortalecer la valorización de materiales reciclables en plantas de manejo de residuos sólidos en pequeños municipios", Ciencia e Ingeniería Neogranadina, vol. 22, no. 1, pp. 59-73, 2012. doi: 10.18359/rcin.249

[4] O. Reyes and F. Reyes, "Comportamiento mecánico y dinámico de una mezcla asfáltica con adición de fibras", Ciencia e Ingeniería Neogranadina, vol. 15, pp. 12-29, 2005. doi: $10.18359 /$ rcin. 1251

[5] H, Rondón, F. Reyes and B. Ojeda, "Comportamiento de una mezcla densa de asfalto en caliente modificada con desecho de policloruro de vinilo (PVC)", Ciencia e Ingeniería Neogranadina, vol. 18, no. 2, pp. 29- 43, 2008. doi:10.18359/rcin.1487

[6] H, Rondón, F. Reyes and B. Ojeda, "Comportamiento de una mezcla densa de asfalto en caliente modificada con desecho de policloruro de vinilo (PVC)", Ciencia e Ingeniería Neogranadina, vol. 18, no. 2, pp. 29- 43 2008. doi:10.18359/rcin. 1487

[7] H. Rondón, J. Ruge, D. Patiño, H. Vacca, F. Reyes and M. de Farías, "Escoria de alto horno como sustituto de la fracción fina de agregados en una mezcla de asfalto", Revista de Materiales en Ingeniería Civil, vol. 30, no. 10, 2018. doi: 10.1061/ (ASCE)MT.1943-5533.0002409

[8] A. Raposeiras, D. Movilla, A. Vargas, R. Bilbao and C. Cifuentes, "Evaluación de rigidez Marshall, tracción indirecta y módulo resiliente en mezclas asfálticas con RAP y escoria de cobre", Revista Ingeniería de construcción, vol. 32, no. 1, pp. 25-36, 2017. doi: 10.4067/ S0718- 50732017000100002

[9] H. Rondón and F. Reyes, "Evaluación de los parámetros mecánicos de una mezcla Asfaltica sometida a las condiciones ambientales de la ciudad de Bogotá D.C.", Revista Ingeniería de construcción, vol. 27, no. 1, pp. 57-74, 2012. doi: $10.4067 /$ S0718-50732012000100004

[10] M. Viloria, L. Cadavid and G. Awad, "Metodología para evaluación de impacto ambiental de proyectos de infraestructura en Colombia", CienciaeIngeniería Neogranadina, vol. 28, no. 2, 2018. doi: 10.18359/rcin.2941

[11] W. Cao, "Study on properties of recycled tire rubber modified asphalt mixtures using dry process", Construction and Building Materials, vol. 21, pp. 1011-1015, 2007. doi: 10.1016/j. conbuildmat.2006.02.004

[12] Universidad de Los Andes, "Estudio de las mejoras mecánicas de mezclas asfálticas con desechos de llantas", Informe fnal contrato IDU- 366-01, Alcaldía Mayor de Bogotá D.C., 2002.

[13] Ministerio de Medio Ambiente, Vivienda y Desarrollo Territorial, "Diagnóstico ambiental sobre generación de llantas usadas", Bogotá D.C., Colombia, 2009.

[14] G. Peláez, S. Velásquez and D. Giraldo, "Aplicaciones de caucho reciclado: una revisión de la literatura", Ciencia e Ingeniería Neogranadina, vol. 27, no. 2, pp. 27-50, 2017. doi: $10.18359 / \mathrm{rcin} .2143$

[15] N. Ramírez, "Estudio de la utilización de caucho de neumáticos en mezclas asfálticas en caliente mediante proceso seco (Memoria para optar el título de Ingeniero civil)", Facultad de Ingeniería Civil, Universidad de Chile, Santiago de Chile, 2006.

[16] J. Gruas, "Efecto de la utilización de mezclas bituminosas con polvo de neumático sobre las características funcionales del pavimento. (Tesis de Especialización)", Departamento de 
Effect of the recycled rubber grain in the rutting of an asphalt mixture type MD-12

Infraestructura del Transporte y Territorio, Universidad Politécnica de Cataluña, Barcelona, 2009.

[17] M. Ocampo, B. Caicedo and D. González, "Mezclas asfálticas mejoradas con caucho molido proveniente de llantas usadas", Universidad de Los Andes. Bogotá D.C., Colombia, 2002.

[18] J. Gallego, “Tecnologías de mezclas bituminosas con caucho de neumáticosExperiencias y normativa española", $X X X V$ Reunión del Asfalto, Rosario-Santa $\mathrm{Fe}$, Argentina, 2008.

[19] Alcaldía Mayor de Bogotá - Secretaría Distrital de Ambiente, "Aprovechamiento de llantas usadas en obras de infraestructura del transporte en el Distrito Capital", Decreto 265 de 2016. Artículo 10, 2016.

[20] C. Acosta, "Asfalto modificado con grano de caucho reciclado (GCR)", Ministerio de Transporte, Bogotá D.C., Colombia, 2015.

[21] A. Dueñas and S. Calume, "Recopilación y análisis sobre el uso de grano de caucho modificado $(\mathrm{GCM})$ para la utilización por vía seca en el diseño de carpetas asfálticas en Bogotá", Facultad de Ingeniería Civil, Universidad, 2017.

[22] E. Rodríguez, "Uso de polvo de caucho de llanta en pavimentos asfalticos", Boletín técnico. PITRA-Lanamme. Universidad de Costa Rica. Costa Rica, 2016.

[23] R. Segovia, "Estudio del efecto de la variación en la granulometría del caucho en mezclas asfálticas por vía seca", Memoria para optar el título de Ingeniero civil. Departamento de Ingeniería Civil, Universidad de Chile, Santiago de Chile, 2007. 